\title{
NUCLEAR CRITICALITY SAFETY EVALUATION OF SRS 9971 SHIPPING PACKAGE (U) wsR-тR--92-565 DE93 012818
}

P. J. Vescovi

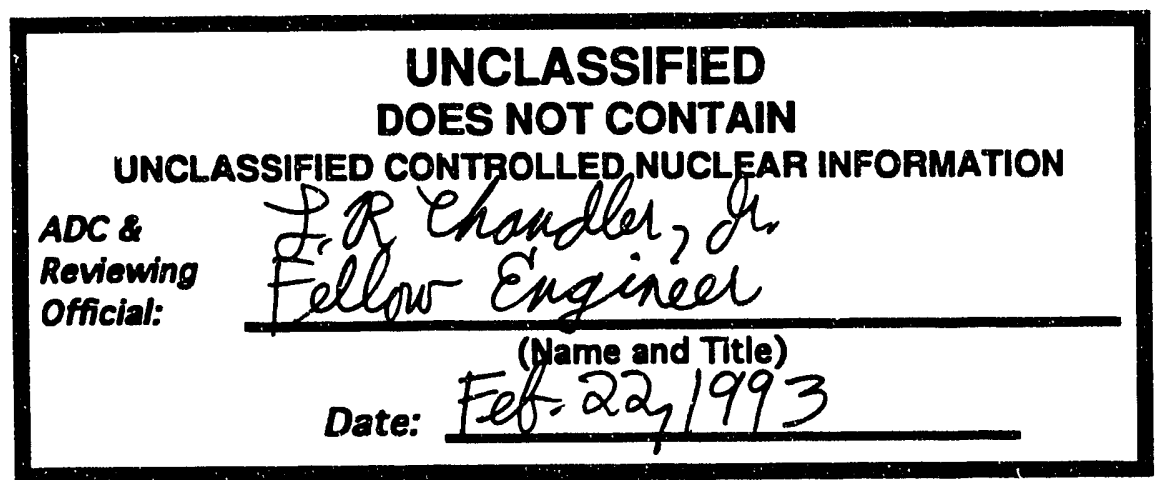

Westinghouse Savannah River Company Savannah River Site Aiken, SC 29808

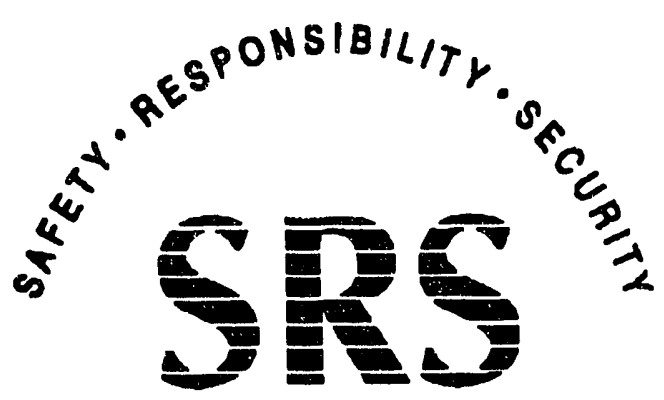

SAVANNAH RIVER SITE

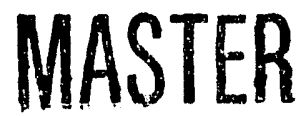


WSRC-TR-92-565

(U)

i

THIS PAGE INTENTIONALLY LEFT BLANK 


\section{CONTENTS}

INTRODUCTION.

SUMMARY

1

NOMINAL VOLUME OF SHIPPING BOTTLE.................................. 1

SHIPPING BOTTLE LIMITS...................................................... 1

SHIPPING PACKAGE LIMITS.................................................... 1

HYDROGENOUS PACKING MATERIAL LIMITS........................... 2

REFERENCES................................................................ 2

AT TACHMENT I...................................................................... 3

CRITICALITY COMPUTATION FOR THE 9971 USF

PACKAGING........................................................................... 4

AT TACHMENT II....................................................................... 5

CRITICALITY EVALUATION.................................................. 6

6.1 Discussion and Results............................................ 6

6.2 Package Fuel Loading............................................... 8

6.3 Model Specification..................................................... 11

6.3.1 DEŚSCFIPYION OF CALCULATION MODELS................ 11

6.3.1.1 9971 Single Package Model......................... 11

6.3.1.2 9971 Undamaged and Damaged Array Model... 11

6.3.2 PACKAGE REgIONAL DENSITIES........................... 17 


\section{CONTENTS (Continued)}

\section{AT TACHMENT II (Continued)}

6.4 Criticality Calculation.............................................. 23

6.4.1 CALCULATION METHOD...................................... 23

6.4.2 FUEL LOADING OPTIMIZATION............................ 23

6.4.3 CRITICALITY RESULT S........................................ 24

6.4.3.1 Single Package Analysls............................. 24

6.4.3.2 Array Analyses........................................ 27

6.4.3.2.1 Mass Limit For Uniiorm Distribution of $\omega_{3} \ln$ Bottlos..................................... 27

6.4.3.2.2 Damaged Finite Array Size Limit..................... 27

6.4.3.2.3 Altemative Materials For Bumed Cane

Fberboard In Damaged Infinite Array............... 32

6.4.3.2.4 O-Ring Material Effects............................ 32

6.4.4 DISPLACEMENT OF INNER CONTAINER IN DAMAGED ARRAY............................................. 32

6.4.5 USE OF SMALLER OR LARGER PLASTIC BOTTLES..... 33

6.5 Criticality Benchmark Experiments............................ 34

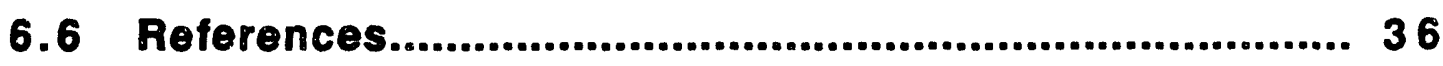




\section{LIST OF FIGURES}

Figure 6-1 Bottle Bulk Mass Limits With Water Present.......................... 10

Figure 6-2 Triangular-Pitch Array To Square-PItch Array Equivalence........ 12

Figure 6-3 Single Package Computational Model................................. 14

Flgure 6-4 Shipplng Package Computational Model............................. 15

Flgure 6-5 ${ }^{\circ}$ Bottle Computational Model..........................................16

Figure 6-6 Results For 9971 Single Package Analysis........................ 26

Figure 6-7 Unlform Distribution of $\mathrm{UO}_{3}$ in Bottles............................. 29

Flgure 6-8 Finite Cublc Array Of Damaged Packages............................ 31

\section{LIST OF TABLES}

TABLE 6-I Summary Of Criticality Evaluation..................................... 6

TABLE 6-II Density Data For $Y-12 \quad$ UO $\mathrm{O}_{3}$ Product................................. 8

TABLE 6-III $\mathrm{UO}_{3}$ Molsture Content Data For Y-12 Product........................ 9

TABLE 6-IV UO Loading Limits For 9971 Shipping Package..................... 9

TABLE 6-V Bottle Bulk Mass Limits With Water Present............................10

TABLE 6-VI Composition of Structural Materials Used In 9971 Analysis...... 18

TABLE 6-VII Composition of $\mathrm{UO}_{3}$-Water Mixtures Used In 9971 Single Package Analysis......................................................... 20

TABLE 6-VIII Composition Of $\mathrm{UO}_{3}$-Air (Vold) -Water Mixtures Used In Damaged 9971 Array Analysis........................................ 21

TABLE 6-IX Results For 9971 Single Package Analysis.......................... 25

TABLE 6-X Results For 9971 Package Array Analysis Mass Limit For Uniform Distribution of $\mathrm{UO}_{3}$ in Bottles............................ 28

TABLE 6-XI Damaged FInite Array.......................................... 30

TABLE 6-XII Error Range/Confldence Level.................................. 34 


\section{APPROVALS}

\section{PROJECT: SRS 9971 Shipping Package Certification}

DOCUMENT: WSRC-TR-92-565 (U)

TITLE:

TASK:

Nuclear Safety Evaluation of SRS 9971 Shipping Package 92-007-H-M-1

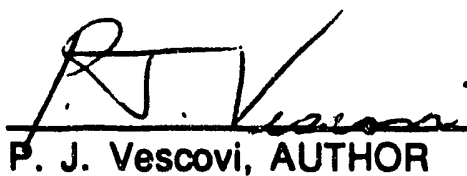

Date: $2-22-93$

Applied Physics Group

SCIENTIFIC COMPUTATIONS SECTION

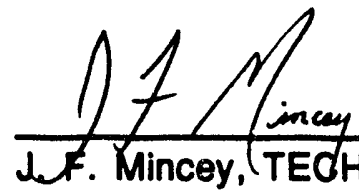

Applied Physics Group

SCIENTIFIC COMPUTATIONS SECTION

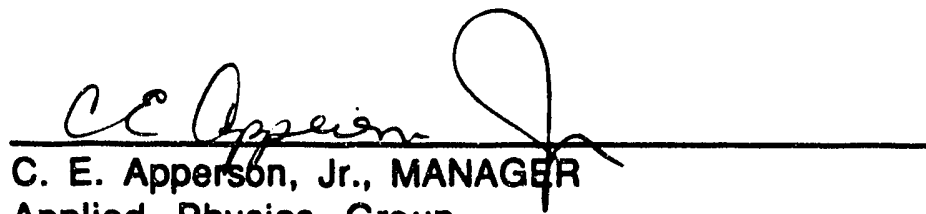

Applied Physics Group

SCIENTIFIC COMPUTATIONS SECTION

M. R. Buckner, MANAGER

Date: $\quad 2 / 22 / 93$

Date: $\quad 2.22 .93$

SCIENTIFIC COMPUTATIONS SECTION 


\title{
NUCLEAR CRITICALITY SAFETY EVALUATION OF SRS 9971 SHIPPING PACKAGE (U)
}

\author{
By P. J. Vescovi \\ Westinghouse Savannah River Company \\ Savannah River Site \\ Aiken, SC 29808
}

\section{INTRODUCTION}

This evaluation is requested to revise the criticality evaluation 1 used to generate Chapter 6 (Criticality Evaluation) of the Safety Analysis Report for Packaging (SARP) for shipment of $\mathrm{UO}_{3}$ product from the Uranium Solidification Facility (USF) in the SRS 9971 shipping package. The pertinent document requesting this evaluation is included as Attachment $I$. The results of the evaluation are given in Attachment II which is written as Chapter 6 of a NRC format SARP.

\section{SUMMARY}

The criticality safety evaluation for the SRS 9971 shipping package has been revised. Recent thermal tests indicate fiberboard insulation damage exceeding pre-test predictions. An infinite array of damaged SRS 9971 shipping packages is not subcritical, but a finite array stacked together in any arrangement not to exceed two thousand (2000) packages is subcritical. Only two hundred fifty packages $(250)$ are required to be subcritical for a Fissile Class I package. IAEA shipping requirements for a TRANSPORT INDEX $=0^{2}$ are not satisfied.

The conclusion of this evaluation is that $\mathrm{UO}_{3}$ product from the USF can be shipped in the SRS 9971 shipping package as FISSILE Class $I^{3}$, provided the following limits are maintained in loading the packages:

Nominal Volume of Shipping Bottle:

- 2.25 Liters not to exceed 2.4 Liters

\section{Shipping Bottle Limits:}

- Maximum Quantity of Dry $\mathrm{UO}_{3}$ per Bottle

$6.5 \mathrm{Kg}$

- Maximum ${ }^{235} \mathrm{U}$ Enrichment of $\mathrm{U}$ in $\mathrm{UO}_{3}$

$80.0 \mathrm{Wt} \%$

- Maximum Added Moisture Content of Product

$6.0 \mathrm{Wt} \%$

Shipping Package Limits:

- Maximum Number of Filled Bottles per Package 
Hydrogenous Packing Material Limits:

- Unlimited Quantities

\section{REFERENCES}

1. Finch, D. R., Nuclear Criticality Safety Evaluation of SRS 8871 Shipping Package, WSRC-TR-91-445, July 1991.

2. International Atomic Energy Agency, Regulation for the Safe Transport of Radioactive Materials, Safety Series No. 65, IAEA, Vienna, Austria 1985.

3. U. S. Code of Federal Regulations, Part 71 - Packaging and Transportation of Radioactive Materials, 10 CFR 71, November 30, 1988. 


\section{ATTACHMENT I}

This attachment contains all documents requesting this evaluation and information requested or supplied pertaining to the evaluation. 
August 4, 1992

TO: JAMES F. MINCEY, 773-22A

COURTNEY E. APPERSON, 773-42A

From: ROBERT S. MAURER, 305-2A R.S.M.

$(5-4728)$

SUBJECT: CRUTICALTYY COMPUTATION FOR THE 9971 USF

PACKAGING (U)

As per our conversation August 3, the Packaging and Transportation Group is requesting your support for the criticality reevaluation of the 9971 Packaging. Due to the results of the 9971 Pool Fire Test the following parameters need to be used in the computation: 1) a 3.1 inch layer of char over the entire cylindrical outer surface of the fiberboard and 2) a 2.5 inch layer of char at the top and bottom surfaces of the fiberboard. The criticality evaluation and chapter upgraded needs to be completed by November.

cc: George A. Lucky, 305-2A

Erich K. Opperman, 305-2A 


\section{ATTACHMENT II}

This attachment contains the detailed results of this nuclear criticality safety evaluation in the format required by the Nuclear Regulatory Commission (NRC) to be Chapter 6 of the Safety Analysis Report for Packaging (SARP) for the 9971 shipping package for $\mathrm{UO}_{3}$ product from the SRS Uranium Solidification Facility. 


\section{CEAPTER 6}

CRITICATITY GYALUATION

\subsection{DISCOSSTON AND RHSOLTS}

A nuclear criticality safety evaluation of the 9971 shipping package was performed. This evaluation was based on a computational analysis ${ }^{l}$ of the shipping package including 1) Single Package Analysis of the water reflected inner container, 2) Array Analysis of undamaged complete packages, and 3) Array Analysis of damaged complete packages. The computational analyses ${ }^{1}$ included determination of optimum interspersed moderation, and determination of optimum fissile material content for maximum reactivity. Results from thermal tests are used to evaluate the damaged package, and the computational analysis ${ }^{1}$ performed prior to the thermal tests is included in this evaluation as applicable. This criticality evaluation complies with all requirements of the ANSI/ANS 8.1 standard ${ }^{2}$, all requirements of DOE order $5480.5^{3}$, and relevant requirements of 10 CFR $71^{4}$.

The results of the computational evaluation of the 9971 package (with fissile loading no greater than specified in Table 6-IV) show that it qualifies for shipment under DOT Fissile Class I regulations 5 . The package does not qualify under IAEA regulations for a transport index of 0 (zero) 6 . These results are summarized in Table 6-I.

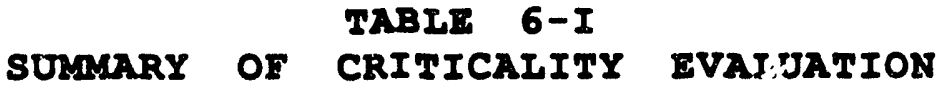

\section{EISSIIE CIASS I}

\section{NORMAI CONDITIONS}

CIASS I

Number of Undamaged Packages Calculated

to be subcritical

Infinite

Optimum Interspersed Hydrogenous Moderation

Dry Air or Void

Package Size, Cubic Centimeters

Inner Container Size, Cubic Centimeters

$144,686 \mathrm{CM}^{3}$ $6,850 \mathrm{CM}^{3}$ 
Number of Damaged Packages Calculated to be subcritical 250

Optimum Interspersed Hydrogenous Moderation

Dry Air or Void

Package Size, Cubic Centimeters Inner Container Size, Cubic Centimeters

$144,686 \mathrm{~cm}^{3}$ $6,850 \mathrm{CM}^{3}$

The highest reactivity calculated in the single package analysis was for the single inner container containing 6.835 $\mathrm{Kg}$. of $\mathrm{UO}_{3}$ uniformly dispersed inside the water flooded and water reflected inner container. This is an optimum condition and is not a maximum allowable mass loading for $\mathrm{UO}_{3}$. The uranium was assumed to be 100 Wt: $235 \mathrm{U}$ in this calculation. In this condition a safety margin of at least 0.15 in Keff was calculated.

The reactivity was calculated for the undamaged infinite array for 1) a maximum loading of $13.0 \mathrm{Kg}$. of dry $\mathrm{UO}_{3}$ at uranium enrichment up to 100 wto 235U, 2) dry air or void interspersed in the array, 3) dry cane fiberboard (no extra water) in the package, 4) no hydrogenous packing material inside the inner container, and 5) no more than 6 wto water content in the $\mathrm{UO}_{3}$. In this condition a safety margin of 0.25 in Keff was calculated.

The damaged infinite array is not subcritical for the same conditions as used to calculate $\mathrm{K}_{\mathrm{eff}}$ for the undamaged infinite array. The $\mathrm{UO}_{3}$ loading would need to be limited to approximately 20 percent of the container capacity in order to ensure subcriticality for the infinite damaged package array under accident conditions and qualify under IAEA regulations for a transport index of 0 (zero) ${ }^{5}$.

A finite array of at least two hundred fifty (250) damaged packages is subcritical for the same conditions used to analyze the undamaged package in an infinite array, with a maximum loading of $13.0 \mathrm{Kg}$. of dry $\mathrm{JO}_{3}$ at uranium enrichment up to 100 Wto $235 \mathrm{U}$. Actual array size used in calculation was $256(8 \times 8 \times 4)$. In this condition a safety margin of 0.30 in $K_{\text {eff }}$ was calculated. The number of packages may be increased to two thousand (2000) and a safety margin of at least 0.05 was calculated. Computational analysis ${ }^{1}$ has shown the calculated reactivity coefficient (Keff) decreases for each of the following changes: 
- Reducing the $\mathrm{UO}_{3}$ content of the package.

- Reducing the water content in the $\mathrm{UO}_{3}$ in the package.

- Introducing any hydrogenous interspersed moderation (in the space between the packages).

- Adding water content to the cane fiberboard inside the outer package container.

- Adding hydrogenous packing material in the space inside the innex container.

\subsection{PACRNG FOMT IONDTKG}

The 9971 shipping package is specified for shipment of $13.0 \mathrm{Kg}$. of dry $\mathrm{UO}_{3}$ in two 2.0-liter high density polyethylene or polypropylene plastic containers. This loading is maximum capacity expected for the shipment of $\mathrm{UO}_{3}$. $\mathrm{UO}_{3}$ is the trioxide compound of uranium that has crystalline density of 7.29 grams/cc. The bulk density of $\mathrm{UO}_{3}$ is dependent upon the specific chemical process used to produce the material. A fine granular $\mathrm{UO}_{3}$ product will have a higher bulk density than a coarse granular $\mathrm{UO}_{3}$ product because interspersed air space increases with grain size. For the purposes of this evaluation, density data for $\mathrm{UO}_{3}$ product from the production process at the $Y-12$ plant in Oak Ridge, TN was used ${ }^{7}$. The chemical process and equipment used in the Y-12 plant are almost identical to that used in the Uranium Solidification Facility (USF) at Savannah River Site (SRS). This data is summarized in the Table 6-II.

\section{Table 6-II \\ Density Date Fox $Y-12$ 003 Product}

Density of $\mathrm{UO}_{3}$ product leaving denitrator Maximum density of $\mathrm{NO}_{3}$ product after settling Maximum density for analysis purposes $(Y-12)$

$$
\begin{array}{r}
3.25 \text { to } 3.5 \mathrm{~g} / \mathrm{cc} \\
3.75 \mathrm{~g} / \mathrm{cc} \\
3.90 \mathrm{~g} / \mathrm{cc}
\end{array}
$$

For purposes of this evaluation the highest credible density of $\mathrm{UO}_{3}$ product was assumed to be $4.0 \mathrm{~g} / \mathrm{Cc}$. This is a sightly more conservative assumption than indicated by the Y-12 data. To achieve this $4.0 \mathrm{~g} / \mathrm{cc}$ density would require special equipment designed to pack the $\mathrm{UO}_{3}$ product beyond what is possible by normal setting. 
The second property of the $\mathrm{UO}_{3}$ product that can affect the criticality safety of the package is the moisture content of the material. Again data from the $Y-12$ plant $\mathrm{UO}_{3}$ product 8 wa- used, and appears in Table 6-III.

\section{Trble 6-III \\ vo3 Moisture Content Data For $Y-12$ Product 8}

Moisture content of nominal product material Maximum moisture content of product material Moisture content at which free pour ceases

For purposes of this evaluation the requirement of criticality safety with water content up to 6 Wto of bulk product weight was used. This limit permits visual detection of excess water content because the product ceases to pour freely before it reaches the 6 Wto limit. For the purposes of the criticality safety evaluation the following limits were used for loading of the bottles shipped in the 9971 package.

\section{Table 6-IV \\ 003 Loading Iimits For 9971 Shipping Package}

Maximum mass of dry $\mathrm{UO}_{3}$ product in 9971 package

Maximum mass of dry $\mathrm{UO}_{3}$ product in any 2.0 -liter bottle

Maximum number of 2.0-liter bottles per 9971 package

Maximum added water in $\mathrm{UO}_{3}$ product

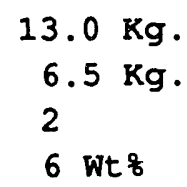

The mass of dry $\mathrm{UO}_{3}$ product excludes the water content. The water content is expressed as a weight percent of bulk mass in the bottle (UO3 mass plus water mass). For reference, Table $6-V$ and Figure $6-1$ show mass limits for bulk product material as a function of wt: water content in the bulk product material. The limiting curve is based on a dry UO 3 content of $6.5 \mathrm{~kg}$. in each bottle.

Full brim capacity of the individual bottles is 2.3 liters. Each bottle loaded to full brim capacity with the highest credible density of $\mathrm{UO}_{3}, 4.0 \mathrm{~g} / \mathrm{Cc}$, would contain 9.15 $\mathrm{Kg}$ dry $\mathrm{UO}_{3}$. The loading limit of $6.5 \mathrm{~kg}$ dry $\mathrm{UO}_{3}$ is considered the actual maximum loading that will be encountered for the density of $\mathrm{UO}_{3}$ product leaving the denitrator. This analysis is for the maximum loading limit of $6.5 \mathrm{Kg}$. mass of dry $\mathrm{UO}_{3}$ product with up to 6 wto water in the bulk product. 
Table 6-V

Bottle Bulk Mass Limits With Water Present

Nitf Fater in Bulk Produat

0

1

2

3

4

5

6

Bulk Yass Iimit For Bottle

$6.500 \mathrm{Kg}$.

$6.566 \mathrm{Kg}$.

$6.633 \mathrm{Kg}$.

$6.701 \mathrm{~kg}$.

$6.771 \mathrm{Kg}$.

$6.842 \mathrm{Kg}$.

$6.915 \mathrm{Kg}$.

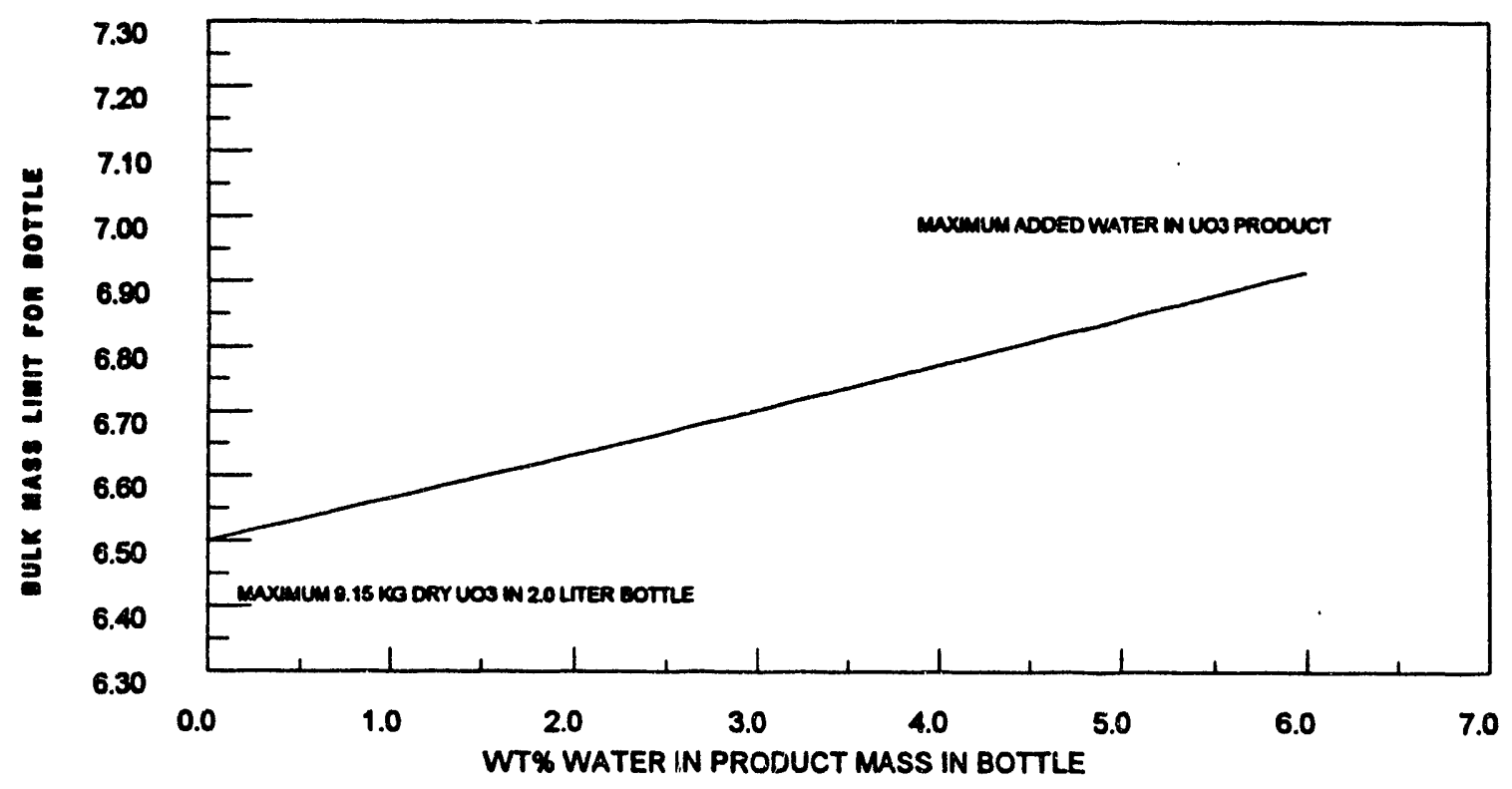

Figure 6-1. Bottle Bulk Mass Iimits With Water Present (REE: TABLE 6-V) 


\subsection{YODFT SPFCTFICATION}

This section will describe the calculation models used in the analysis of criticality safety for the 9971 shipping package.

\subsubsection{Description of Calculation Nodels}

\subsubsection{9971 Single Package Model}

The single package analysis model considered only the inner container of the 9971 package filled with a mixture of $\mathrm{UO}_{3}$ product and water. The inner container was reflected by a minimum of $50 \mathrm{~cm}$. (19.65 inches) of water on all sides which constitutes an effectively infinite reflector. The calculation model is shown in Figure 6-3 and was derived from Engineering Drawings listed in Reference 9.

The product material-water mixture was assumed to occupy varying volumes of the inner container as shown in Figure 6-3 with all remaining volume filled with water.

The single package analysis model ignores the presence of plastic bottles, and optional packing materials within the inner container that could be admixed with the $\mathrm{UO}_{3}$ product thus reducing the $\mathrm{H} / \mathrm{U}$ atom ratios that are possible inside the container. In addition, including the bottle materials and packing could introduce mild neutron poisons (such as chlorine) into the calculation which could reduce the calculated reactivity coefficient (Keff). The admixed water within the $\mathrm{UO}_{3}$ product represents a greater quantity of hydrogen than could be provided by any credible packing material, hence represents a worse case (normally higher calculated Keffl than explicitly modeling the packing materials.

\subsubsection{9971 Undamaged and Damaged Array Model}

The array analysis model considered cubic arrays of packages that extend to infinity in all directions, and finite arrays closely reflected with water on all sides. The calculation model is shown in Figure 6-4 and was derived from Engineering Drawings listed in Reference 10. The outer diameter of the 35-galion type $17 \mathrm{C}$ drum was reduced by $7 \%$ to 
equate a triangular-pitch array to the square-pitch array used in the calculations. The basis of this $7 \%$ reduction in diameter is to equate the area occupied by the drum in a triangular-pitch array to the area occupied by the drum in the square-pitch array, and is shown in the following diagram.

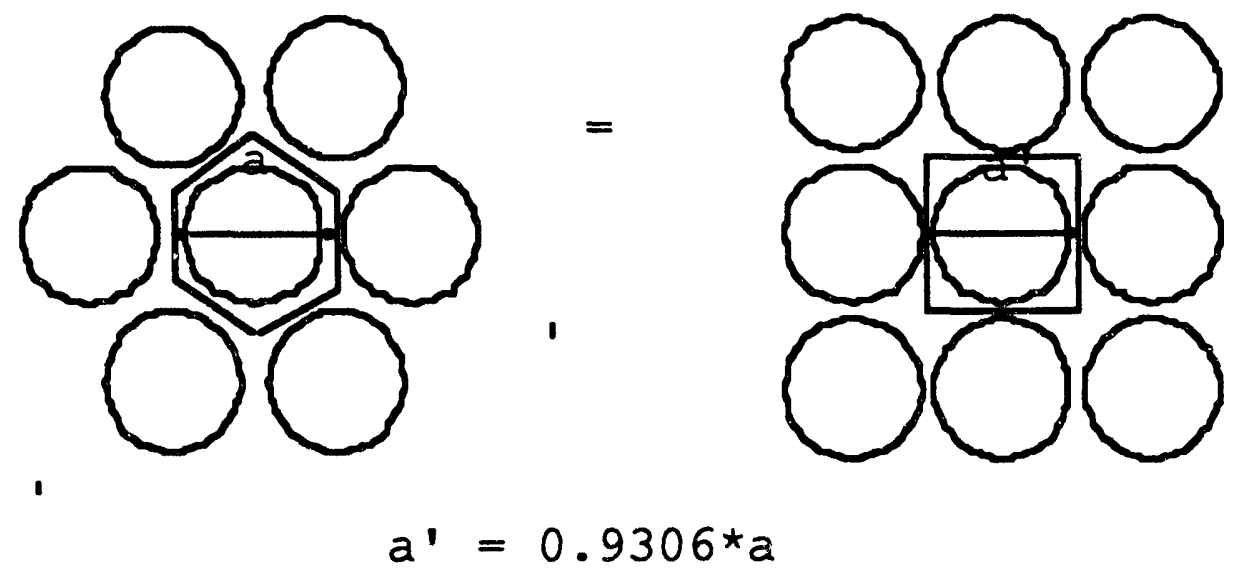

Figure 6-2. Triangular-Pitch Array To Square-Pitch Array Equivalence

The dimensions used in the calculations are shown in Figure 6-4 with dimensions for the inner container shown in Figure $6-3$.

The same array model was used for undamaged and damaged arrays by replacing the material in the burned cane fiberboard region (damaged model) with normal cane fiberboard (undamaged model). As mentioned, it was not possible to show an infinite array acceptable and the damaged array calculation has finite boundaries.

The UO3 product was confined to the two bottles shown in Figure 6-4. The calculation model for the bottles is shown in Figure 6-5 and was constructed from manufacturer's specifications and measurements of an actual bottle listed in Reference 13. Partially filled bottles were modeled by placing the $\mathrm{UO}_{3}$ product in the region designated $\mathrm{UO}_{3}$, and filling the rest of the bottle with dry air in the region so 
designated. The region in the inner container surrounding the two bottles was filled with dry air or a variety of packing materials depending on the calculation. The bottles were sized to a volume of 2.29 liters, although the manufacturer's specification 11 gives a maximum brim capacity for this bottle of up to 2.2 liters.

In the damaged package model a low density carbon material (to simulate fiberboard ash) was placed in the burned cane fiberboard region shown in Figure 6-4. The low density carbon material is defined in Table 6-VI, and represents about the same carbon content as in the original fiberboard. The burned cane fiberboard region was modeled as a 3.1 inch layer over the entire cylindrical outer surface 


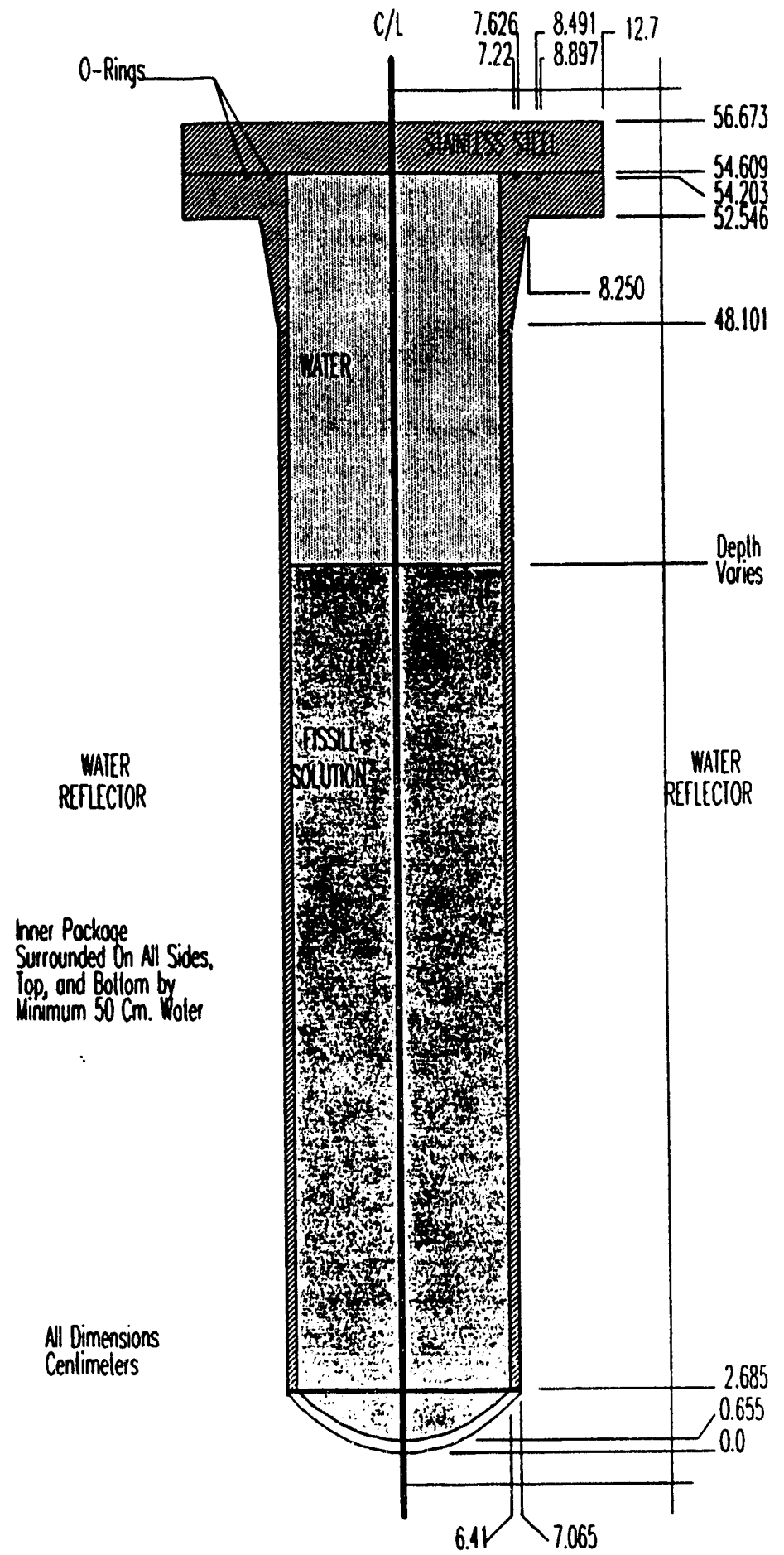

Figure 6-3. Single Package Computational Model 


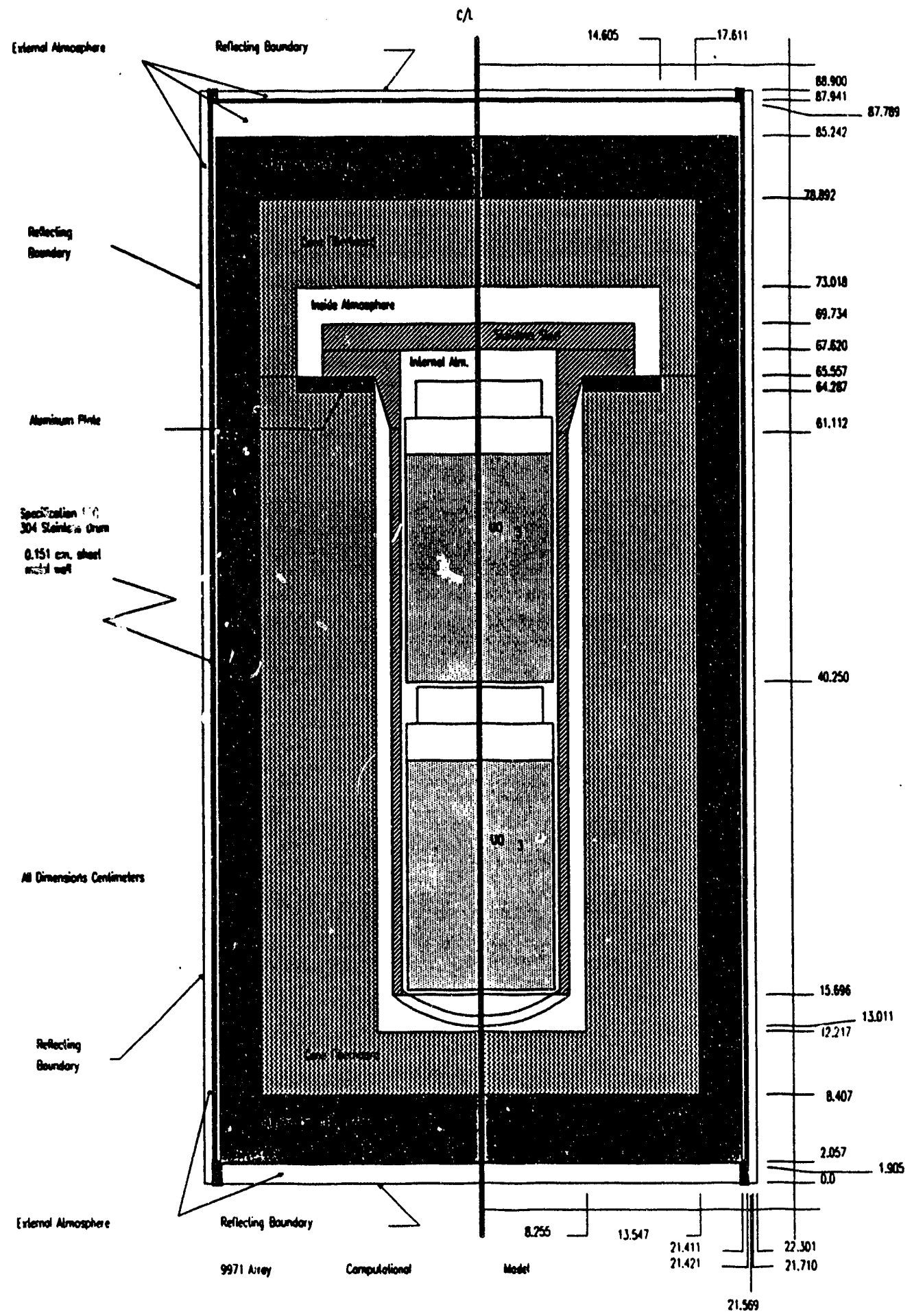

Figure 6-4. Shipping Package Computational Model 


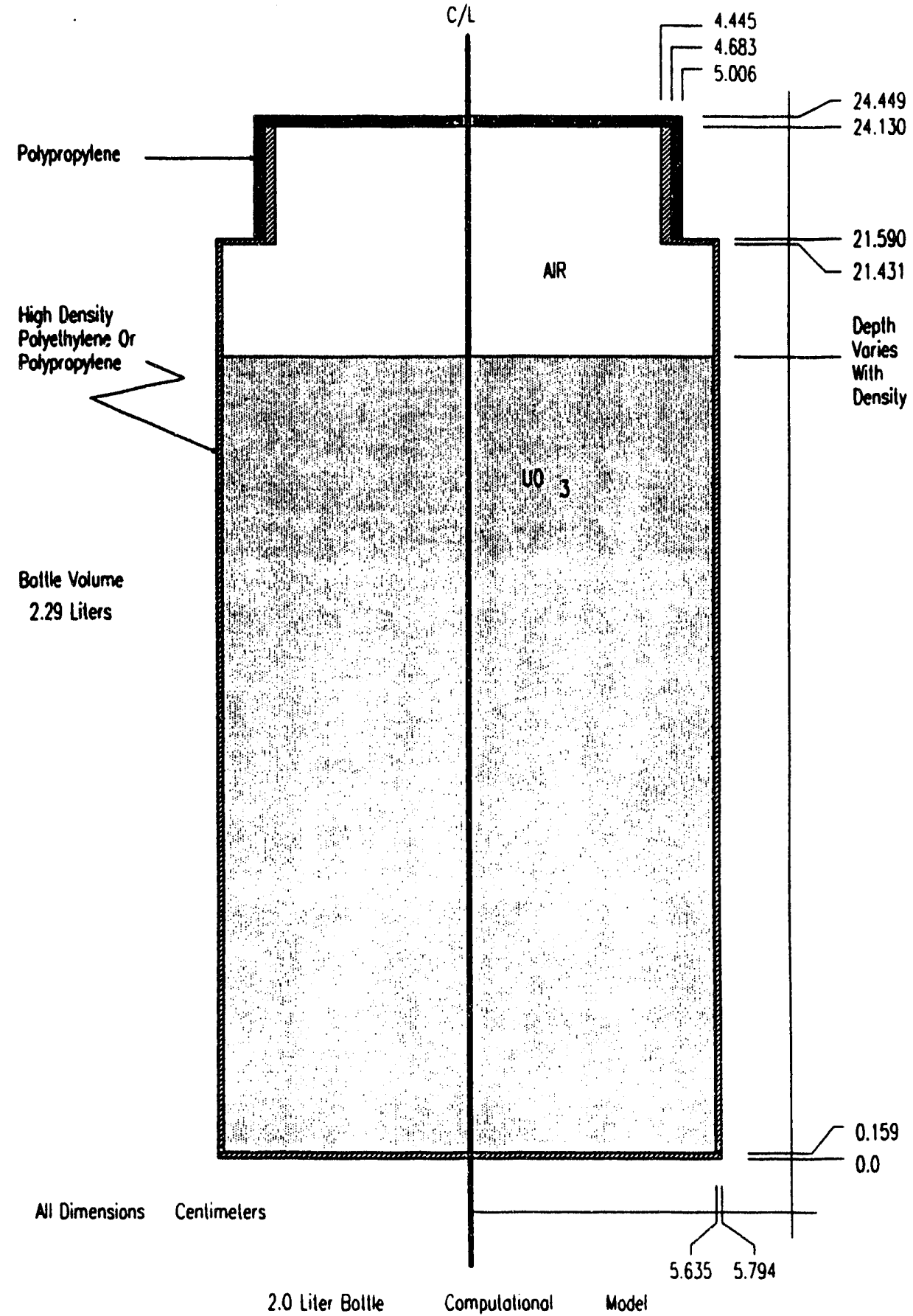

Figure 6-5. Bottle Computational Model 
of the fiberboard, and a 2.5 inch layer at the top and bottom surfaces of the fiberboard to reflect the results of thermal tests. 12

The calculation model was constructed so that materials in each region in Figure $6-4$ could be changed to determine the Keff sensitivity to the change. The following material regions could be specified uniquely.

- $\mathrm{UO}_{3}$ product mixture in each bottle separately.

- Atmosphere in the unfilled region of each bottle separately.

- Packing material surrounding the bottles inside the inner container.

- Material in the stainless steel inner container.

- Atmosphere in the air space inside the package outside the inner container.

- Composition of the cane fiberboard.

- Composition of the burned cane fiberboard.

- Atmosphere outside the outer drum (interspersed region).

By changing selected materials over a range of credible compositions, the criticality behavior of the 9971 package array has been determined for credible normal and abnormal conditions. 1

\subsubsection{Package Regienal Densities}

Composition and atomic number densities for all structural materials used in calculations are shown in Table 6-VI. The composition used for dry cane fiberboard has a density of $0.2 \mathrm{gm} / \mathrm{cc}$ compared to the minimum specified density of 0.24 $\mathrm{gm} / \mathrm{cc}$ on engineering drawings 13 . This $16 \%$ reduction permits miscellaneous holes to be drilled in the fiberboard with no compromise in safety. This reduction in density increased Keff in calculations by a small amount.

Composition and atomic number densities for 100 wt $235 \mathrm{U}$ enrichment UO3-water mixtures used in the single package analysis are shown in Table 6-VII. 
Composition and atomic number densities for 80 wt 8 and $100 \mathrm{Wt} \% 235 \mathrm{U}$ enrichment $\mathrm{UO}_{3}$-air(void)-water( 6 Wt $\%$ ) mixtures used in the damaged and undamaged array analyses are shown in Table 6-VIII.

Table 6-VI

Composition of Structural Materials Used In 9971 Analysis

Container Matorials

$$
\text { MATERIAL }
$$

Stainless Steel

Dry Air

Neoprene Rubber

Buna-N Rubber
DENSITY (G/CM3)

7.895

0.0012

1.229

0.978
ISOTOPE WT\%

$\begin{array}{cr}\mathrm{C} & 0.08 \\ \mathrm{Cr} & 18.01 \\ \mathrm{Mn} & 2.00 \\ \mathrm{Fe} & 70.90 \\ \mathrm{Ni} & 8.01\end{array}$

Si

N

0

c

CI

$\mathrm{H}$

C

N

H
1.00

77.791

22.209

54.265

40.043

5.692

78.463

13.072

8.465
ATOMS/B-CM

3. 1691E-04

1. $6471 \mathrm{E}-02$

1. $7321 \mathrm{E}-03$

$6.0360 \mathrm{E}-02$

$6.4834 \mathrm{E}-03$

1. $6940 \mathrm{E}-03$

4.013E-05

1. $003 E-05$

3. 3438E-02

8. 3595E-03

4. $1795 \mathrm{E}-02$

3. $9484 \mathrm{E}-02$

$5.4966 E-03$

$4.9462 \mathrm{E}-02$

Plastic Materials

\section{MATERIAL}

Polypropylene

Polyethylene

(Medium Density)

Polyethylene

(High Density)
DENSITY

(G/CM3)

0.90

0.925

0.95
ISOTOPE

C

H

C

H

C.

H
WT웅

85.628

14.372

85.628

14.372

85.628

14.372
ATOMS / B-CM

3. $8848 \mathrm{E}-02$

$7.7696 \mathrm{E}-02$

3. $9927 \mathrm{E}-02$

$7.9854 \mathrm{E}-02$

4. 1010E-02

8. 2012E-02 
Water

$\begin{array}{rlcll}\text { MATERIAL } & \begin{array}{c}\text { DENSITY } \\ \text { (G/CM3) }\end{array} & \text { ISOTOIE } & \text { WT\% } & \text { ATOMS/B-CM } \\ \text { Full Density } & 0.99820 & \mathrm{O} & 88.1 & 3.3369 \mathrm{E}-02 \\ & & \mathrm{H} & 11.19 & 6.6738 \mathrm{E}-02 \\ 10 \% \text { Density } & 0.09982 & \mathrm{O} & 88.1 & 3.3369 \mathrm{E}-03 \\ & & \mathrm{H} & 11.19 & 6.6738 \mathrm{E}-03 \\ \text { 1\% Density } & 0.009982 & \mathrm{O} & 88.1 & 3.3369 \mathrm{E}-04 \\ & & \mathrm{H} & 11.19 & 6.6738 \mathrm{E}-04\end{array}$

Normal Cane Fiberboard

\begin{tabular}{|c|c|c|c|c|c|c|}
\hline & & ATERIAL & DENSITY & ISOTOPE & WT $\%$ & ATOMS/B-CM \\
\hline \multirow[t]{3}{*}{ Dry } & & & 0.20 & 0 & 49.337 & $3.7141 E-03$ \\
\hline & & & & $\mathrm{C}$ & 44.446 & $4.4569 \mathrm{E}-03$ \\
\hline & & & & $\mathrm{H}$ & 6.217 & $7.4282 E-03$ \\
\hline \multirow[t]{3}{*}{20} & Wt $\frac{8}{8}$ & Water & 0.25 & 0 & 57.234 & $5.3971 E-03$ \\
\hline & & & & C & 35.555 & $4.4569 \mathrm{E}-03$ \\
\hline & & & & $\mathrm{H}$ & 7.211 & $1.0772 \mathrm{E}-02$ \\
\hline \multirow[t]{3}{*}{40} & Wt $q$ & Water & 0.33 & 0 & 65.126 & $8.7109 E-03$ \\
\hline & & & & $\mathrm{C}$ & 26.668 & $4.4569 E-03$ \\
\hline & & & & $\mathrm{H}$ & 8.206 & $1.6342 \mathrm{E}-02$ \\
\hline \multirow[t]{3}{*}{60} & Wt $\%$ & Water & 0.50 & 0 & 73.021 & $1.3743 \mathrm{E}-02$ \\
\hline & & & & C & 17.778 & $4.4569 E-03$ \\
\hline & & & & $\mathrm{H}$ & 9.201 & $2.7495 E-02$ \\
\hline \multirow[t]{3}{*}{80} & Wt 8 & Water & 1.0 & 0 & 80.915 & $3.0457 \mathrm{E}-02$ \\
\hline & & & & C & 8.889 & $4.4569 E-03$ \\
\hline & & & & $\mathrm{H}$ & 10.195 & $6.0914 \mathrm{E}-02$ \\
\hline
\end{tabular}

Burned Cane Fiberboard

\begin{tabular}{lllll}
\multicolumn{1}{c}{ MATERIAL } & $\begin{array}{l}\text { DENSITY } \\
\text { (G/CM3) }\end{array}$ & ISOTOPE & WT\% & ATOMS/B-CM \\
0.5 X Normal & 0.049585 & $\mathrm{C}$ & 100 & $2.4493 \mathrm{E}-03$ \\
Normal Density & 0.0997 & $\mathrm{C}$ & 100 & $4.9986 \mathrm{E}-03$ \\
$2 \mathrm{X}$ Normal & 0.1994 & $\mathrm{C}$ & 100 & $9.9972 \mathrm{E}-03$ \\
$4 \mathrm{X}$ Normal & 0.3988 & $\mathrm{C}$ & 100 & $1.9994 \mathrm{E}-02$
\end{tabular}




\section{Table 6-VII \\ Composition of $\mathrm{UO}_{3}$-Water Mixtures \\ Used In 9971 single Package Analysis}

Uranium in UO3 Assumed $100 \%$ Enrichment $235 \mathrm{U}$

$\begin{array}{rrrrr}\text { MIXTURE } & \begin{array}{c}\text { DENSITY } \\ (G / C C)\end{array} & \text { WT\& } 235 U & \text { WT\& } O & \text { WT\& } H \\ \text { IW } & 4.4445 & 74.732 & 24.148 & 1.120 \\ 2 W & 4.1442 & 73.163 & 25.506 & 1.331 \\ \text { 3W } & 3.7983 & 71.049 & 27.335 & 1.616 \\ 4 W & 3.4968 & 68.865 & 29.225 & 1.910 \\ 5 W & 3.0658 & 64.997 & 32.571 & 2.432 \\ 6 W & 2.6370 & 59.894 & 36.987 & 3.119 \\ 7 W & 2.2906 & 54.378 & 41.760 & 3.862 \\ 8 W & 1.8598 & 44.649 & 50.178 & 5.173 \\ \text { 9W } & 1.5170 & 32.959 & 60.292 & 6.149 \\ 10 W & 1.2576 & 19.879 & 71.610 & 8.511\end{array}$

Mixture Number Densities (Atoms/B-cm)

\begin{tabular}{rrrr} 
MIXTURE & \multicolumn{2}{l}{$235 \mathrm{U}$} & \multicolumn{2}{l}{$\mathrm{H}$} \\
IW & $8.5102 \mathrm{E}-03$ & $4.0398 \mathrm{E}-02$ & $2.9735 \mathrm{E}-02$ \\
$2 W$ & $7.7684 \mathrm{E}-03$ & $3.9785 \mathrm{E}-02$ & $3.2960 \mathrm{E}-02$ \\
$3 W$ & $6.9145 \mathrm{E}-03$ & $3.9080 \mathrm{E}-02$ & $3.6673 \mathrm{E}-02$ \\
$4 W$ & $6.1699 \mathrm{E}-03$ & $3.8465 \mathrm{E}-02$ & $3.9911 \mathrm{E}-02$ \\
$5 W$ & $5.1056 \mathrm{E}-03$ & $3.7586 \mathrm{E}-02$ & $4.4539 \mathrm{E}-02$ \\
$6 \mathrm{~W}$ & $4.0466 \mathrm{E}-03$ & $3.6712 \mathrm{E}-02$ & $4.9143 \mathrm{E}-02$ \\
$7 W$ & $3.1914 \mathrm{E}-03$ & $3.6005 \mathrm{E}-02$ & $5.2862 \mathrm{E}-02$ \\
$8 W$ & $2.1276 \mathrm{E}-03$ & $3.5127 \mathrm{E}-02$ & $5.7487 \mathrm{E}-02$ \\
$9 W$ & $1.2811 \mathrm{E}-03$ & $3.4427 \mathrm{E}-02$ & $6.1168 \mathrm{E}-02$ \\
$10 \mathrm{~W}$ & $6.4054 \mathrm{E}-04$ & $3.3898 \mathrm{E}-02$ & $6.3953 \mathrm{E}-02$
\end{tabular}

$\begin{array}{rcc}\text { MIXTURE } & \begin{array}{l}\mathrm{UO}_{3} \\ (\mathrm{KG} .)\end{array} & \mathrm{H} / 235 \mathrm{U} \text { RATIO } \\ 1 W & 13.0 & 3.494 \\ 2 W & 13.0 & 4.243 \\ 3 W & 13.0 & 5.304 \\ 4 W & 13.0 & 6.469 \\ 5 W & 13.0 & 8.724 \\ 6 W & 13.0 & 12.14 \\ 7 W & 10.25 & 16.56 \\ 8 W & 6.835 & 27.02 \\ 9 W & 4.116 & 47.75 \\ 10 W & 2.058 & 99.84\end{array}$




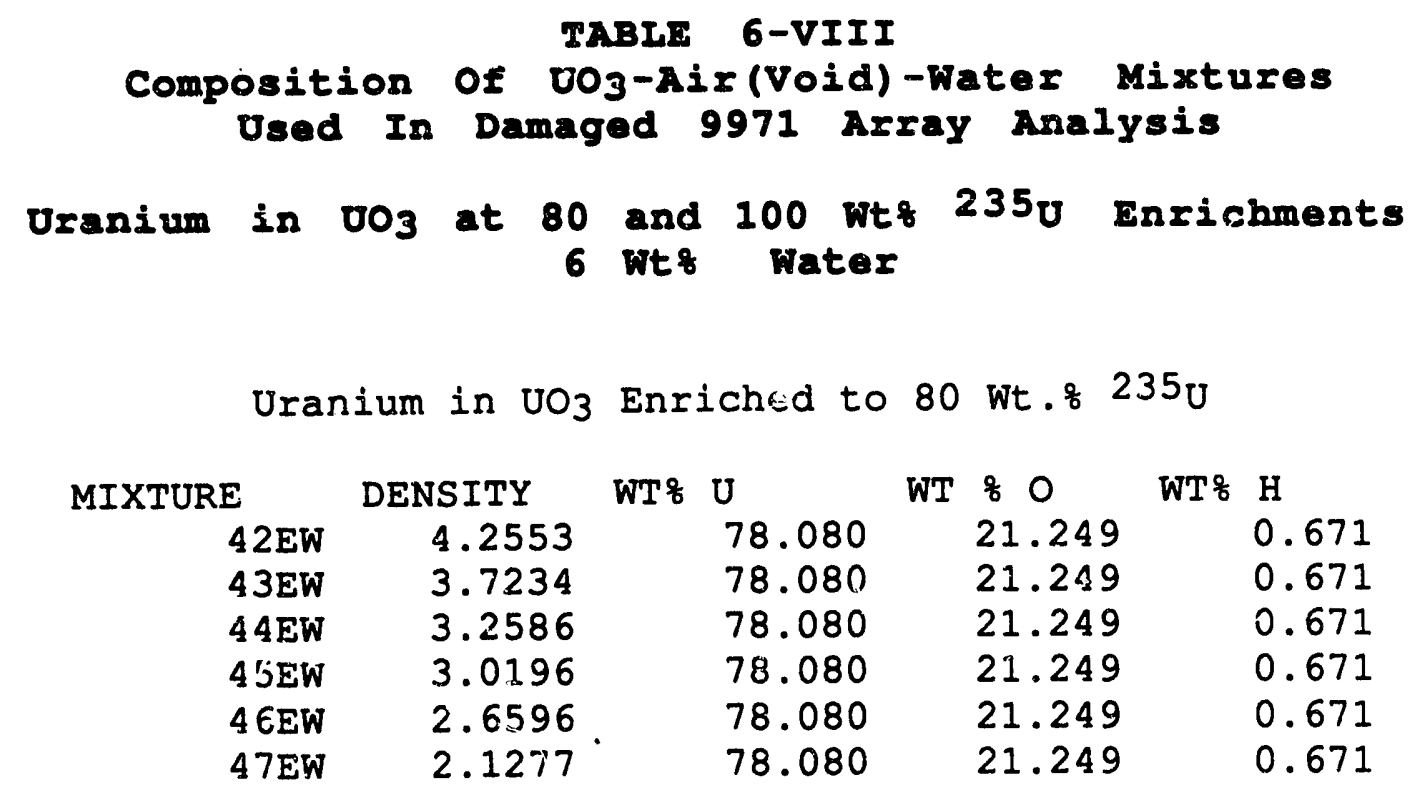

Uranium in UC3 Fnriched to $100 \mathrm{Wt} .8235 \mathrm{U}$

$\begin{array}{lllll}48 \mathrm{EW} & \$ .2553 & 78.060 & 21.269 & 0.671 \\ 49 \mathrm{EW} & 3.7234 & 78.060 & 21.269 & 0.671 \\ 50 \mathrm{EW} & 3.2586 & 78.060 & 21.269 & 0.671 \\ 51 \mathrm{EW} & 3.0196 & 78.060 & 21.269 & 0.671 \\ 52 \mathrm{EW} & 2.6596 & 78.060 & 21.269 & 0.671 \\ 53 \mathrm{EW} & 2.1277 & 78.060 & 21.269 & 0.671\end{array}$


Table 6-VIII (CONTINUED)

Composition of $\mathrm{OO}_{3}$-Air(Void)-Water Mixtures

Used In Damaged 9971 Array Analysis

\section{Mixture Number Densities (Atoms/B-cm)}

$\begin{array}{cr}\text { MIXTURE } & 234 \mathrm{U} \\ 42 \mathrm{EW} & 8.9340 \mathrm{E}-05 \\ 43 \mathrm{EW} & 7.8173 \mathrm{E}-05 \\ 44 \mathrm{EW} & 6.8414 \mathrm{E}-05 \\ 45 \mathrm{EW} & 6.3396 \mathrm{E}-05 \\ 46 \mathrm{EW} & 5.5838 \mathrm{E}-05 \\ 47 \mathrm{EW} & 4.4671 \mathrm{E}-05 \\ 48 \mathrm{EW} & \\ 49 \mathrm{EW} & \\ 50 \mathrm{EW} & \\ 51 \mathrm{EW} & \\ 52 \mathrm{EW} & \\ 53 \mathrm{EW} & \end{array}$

$235 \mathrm{U}$

$6.8103 \mathrm{E}-03$

5. $9590 \mathrm{E}-03$

5.2151E-03

$4.8326 \mathrm{E}-03$

4. $2564 E-03$

$3.4052 \mathrm{E}-03$

8.5105E-03

$7.4467 E-03$

$6.5550 \mathrm{E}-03$

$6.0392 \mathrm{E}-03$

$5.3192 \mathrm{E}-03$

$4.2554 \mathrm{E}-03$
$236_{\mathrm{U}}$

$$
\text { 8. 3233E-04 }
$$

$7.2829 \mathrm{E}-04$

$6.3737 E-04$

$5.9062 \mathrm{E}-04$

$5.2020 \mathrm{E}-04$

4. 1617 E-04

$\begin{array}{cr}\text { MIXTURE } & 238 \mathrm{U} \\ \text { 42EW } & 7.6791 \mathrm{E}-04 \\ \text { 43EW } & 6.7192 \mathrm{E}-04 \\ \text { 44EW } & 5.8804 \mathrm{E}-04 \\ \text { 45EW } & 5.4491 \mathrm{E}-04 \\ 46 \mathrm{EW} & 4.7994 \mathrm{E}-04 \\ \text { 47EW } & 3.8396 \mathrm{E}-04 \\ \text { 48EW } & \\ \text { 4 9EW } & \\ \text { 50EW } & \\ \text { 51EW } & \\ \text { 52EW } & \\ \text { 53EW } & \end{array}$

0

3. $4034 \mathrm{E}-02$

2. $9780 \mathrm{E}-02$

2. $6062 \mathrm{E}-02$

2. $4151 \mathrm{E}-02$

2.1271E-02

1. 7017E-02

3. $4066 \mathrm{E}-02$

2. $9808 \mathrm{E}-02$

2. 6239E-02

$2.4174 \mathrm{E}-02$

$2.1292 \mathrm{E}-02$

1. $7034 \mathrm{E}-02$
$\mathrm{H}$

1.7070E-02

$1.4936 \mathrm{E}-03$

1. 3071E-03

1. 2113E-02

$1.0669 \mathrm{E}-02$

8.5349E-03

1. $7069 \mathrm{E}-02$

$1.4936 \mathrm{E}-03$

1. $3147 E-03$

1. 2113E-02

1. $0669 \mathrm{E}-02$

$8.5350 E-03$
H/235U RATIO

2.506

2.506

2.506

2.506

2.506

2.506

2.006

2.006

2.006

2.006

2.006

2.006 


\subsection{CRITICAIITY CAICUIATION}

\subsubsection{Calavlation Method}

The single package analysis and the array analyses were based on calculated results from the multi-group Monte Carlo criticality code Karo-IV/CG14 using the 16 energy-group Hansen-Roach cross section library 15 . Mixture cross sections were prepared using the $\operatorname{HRxN}^{16}$ module of the Korol7 system. These computer codes were chosen because of their ability to accurately model the geometry of the problem, and because they have been extensively validated against more than 500 critical experiments with a range of $235 \mathrm{U}$ enrichments using the Hansen-Roach cross section library. The validation will be discussed in Section 6.5 .

\subsubsection{Evel Ioading Optimination}

The optimum loading of the 9971 package is that fuel content and configuration that corresponds to the highest value of the reactivity coefficient $\left(\mathrm{K}_{\mathrm{e} f f}\right)$. This information has been determined ${ }^{1}$, and is here summarized for single package and array analyses.

In the single package analysis, the $\mathrm{UO}_{3}$-water mixture was varied over a range corresponding to water weight fractions from 0.10 to 0.76 . The $H / 235 \mathrm{U}$ atom ratios range from 3.5 to 100 for the 100 wto $235 \mathrm{U}$ enrichment in these calculations. The maximum reactivity for $\mathrm{UO}_{3}$-water mixtures has been determined 1 which corresponded to the optimum H/235 atom ratio and the optimum $\mathrm{UO}_{3}$ loading for the single inner package.

In the previous undamaged and damaged array analyses ${ }^{1}$ the effects of $\mathrm{UO}_{3}$ distribution in the bottle and material composition in regions of the package were examined. The changes included the following:

- Changing the hydrogenous packing material inside the inner container.

- Changing the hydrogen content in the normal cane fiberboard.

- Changing the hydrogen content in the interspersed atmosphere between packages.

- Changing the hydrogen content in the atmosphere internal to the package external to the inner container.

- Changing the composition of burned cane fiberboard. 
The optimum condition for the highest reactivity coefficient ( $K_{e f f}$ ) for the damaged package is obtained with the following conditions (Assuming two bottles of $\mathrm{UO}_{3}$ product in each package):

- Each bottle loaded with $6.5 \mathrm{~kg}$. dry UO3 at $100 \mathrm{Wt} . \frac{8}{8}$ enrichment $235 \mathrm{U}$ and $6 \mathrm{Wt}$ water added $\left(6.915 \mathrm{Kg}\right.$. bulk $\mathrm{UO}_{3}$ product mass).

- Dry air or void interspersed between packages in the array.

- Dry cane fiberboard material in the package.

- Dry air or void with no hydrogenous packing materials in the inner container.

- Low density carbon material, dry air, or void in the burned cane fiberboard region.

Under normal shipping conditions the undamaged 9971 package is subcritical with a safety margin of at least 0.14 in Keff with two bottles containing $13.0 \mathrm{Kg}$. of $\mathrm{UO}_{3}$-water mixture with 100 wt $235 \mathrm{U}$ enrichment and 6 wt 8 water.

\section{4 .3 criticality Resulta}

\subsubsection{Single Package Analysis}

Calculated results for the single inner container analysis are shown in Table 6-IX, and Figure 6-6. The maximum reactivity coefficient (Keff) occurs at a package loading of $6.835 \mathrm{Kg}$. of $\mathrm{UO}_{3}$ product fully water saturated. This occurs because the optimum $\mathrm{H} / 235 \mathrm{U}$ is achieved at a value that requires water to replace some of the $\mathrm{UO}_{3}$ product. "wo effects are occurring in the calculations shown in Table 6-IX and Figure 6-6:

1. The reactivity coefficient (Keff) increases with increasing $\mathrm{H} / 235 \mathrm{U}$ atom ratio.

2. The reactivity coefficient (Keff) decreases with decreasing $235 \mathrm{U}$ content in the package.

It is apparent from the results that the first effect is most important for this package.

The calculated results demonstrate that the single inner package loaded with optimum quantity of $\mathrm{UO}_{3}$ and under optimum water flooding and water reflection conditions is subcritical with a minimum safety margin of 0.155 in Keff. 
Table 6-IX

\section{Results For 9971 Single Package Analysis}

\section{$13 \mathrm{Kg}$. Dry 003 Fully Water Flooded \\ $50 \mathrm{~cm}$. Water Reflected Inner Package}

\begin{tabular}{|c|c|c|c|c|c|}
\hline MIXTURE & $\mathrm{UO}_{3}$ & (KG/BОT . ) & CALCULATED $K_{e f f}{ }^{1}$ & $K_{\text {eff }}$ BIAS $^{2}$ & MAX. Keff \\
\hline $1 W$ & & 6.5 & $0.70886 \pm 0.00417$ & +0.030 & 0.751 \\
\hline $2 W$ & & 6.5 & $0.71912 \pm 0.00435$ & +0.030 & 0.762 \\
\hline $3 W$ & & 6.5 & $0.73848 \pm 0.00487$ & +0.030 & 0.783 \\
\hline $4 W$ & & 6.5 & $0.76285 \pm 0.00464$ & +0.030 & 0.807 \\
\hline $5 W$ & & 6.5 & $0.76919 \pm 0.00540$ & +0.030 & 0.815 \\
\hline $6 \mathrm{~W}$ & & 6.5 & $0.79509 \pm 0.00481$ & +0.030 & 0.840 \\
\hline $7 \mathrm{~W}$ & & 5.125 & $0.79246 \pm 0.00533$ & +0.030 & 0.838 \\
\hline $8 W$ & & 3.4175 & $0.80029 \pm 0.00495$ & +0.030 & 0.845 \\
\hline $9 w$ & & 2.058 & $0.78956 \pm 0.00499$ & +0.030 & 0.835 \\
\hline $10 \mathrm{~W}$ & & 1.029 & $0.75689 \pm 0.00525$ & +0.030 & 0.803 \\
\hline
\end{tabular}

1 - Uncertainties are one standard deviation $167 \%$ Confidence).

2 - H. K. Clark, "Subcritical Limits for 235 U Systems", Nuc. Sci.s Engr. Vol 81 (1982).

3 - Max. Keff = Calculated Keff +3 Std. Dev. + Keff Bias Max. Keff cannot exceed 0.95 to assure a minimum safet margin of 0.05 in $K_{e f f}$. 


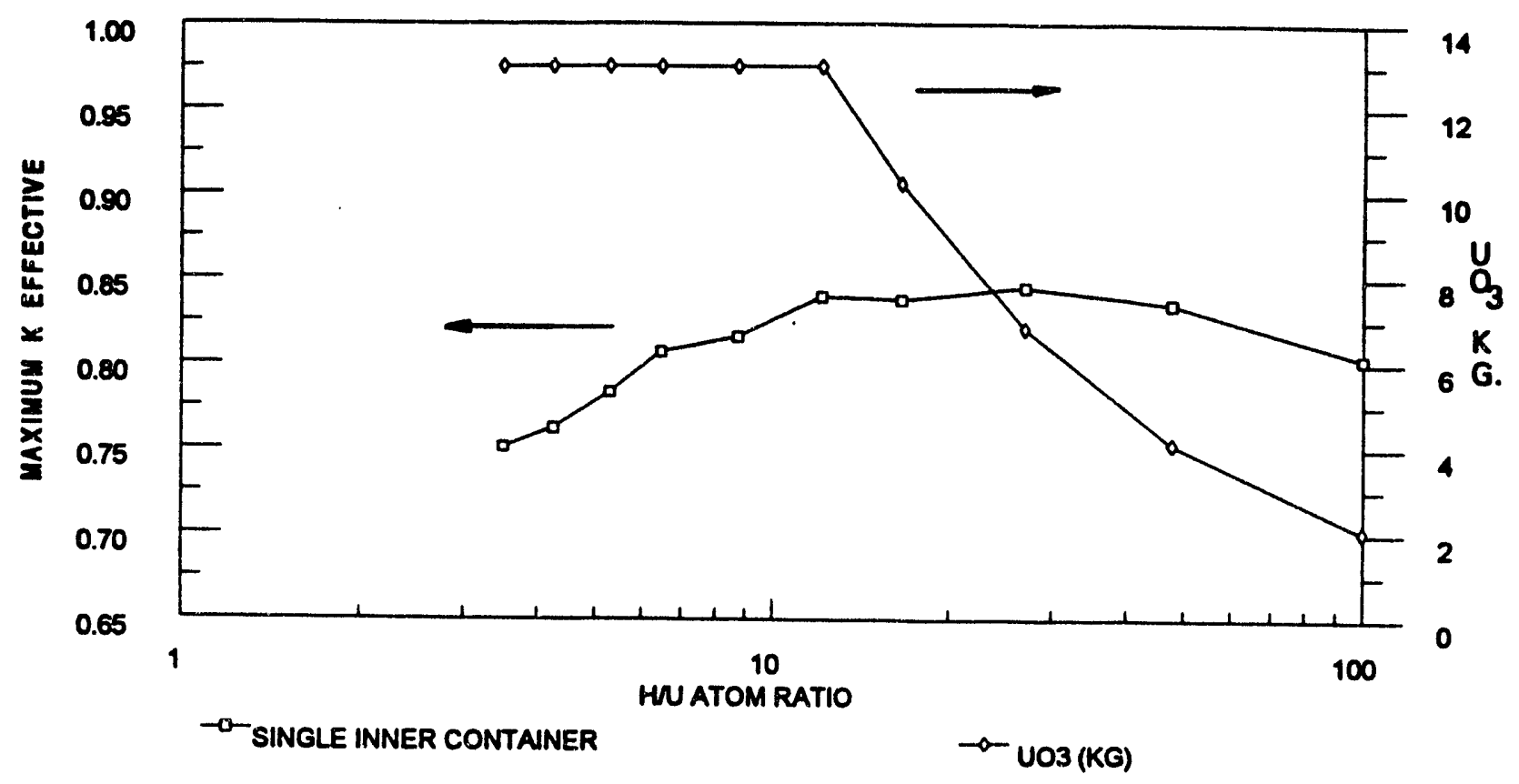

Figure 6-6. Results For 9971 Single Package Analysis (REF: TABLE 6-IX) 


\subsubsection{Array Analyses}

Several sets of calculations were performed to determine the optimum reactivity configuration of the undamaged and damaged 9971 package.

\subsection{Mass Iimit For Oniform Distribution of $00_{3}$ In Bottles}

Calculations were performed to determine the subcritical margin for a range of mass loading of $\mathrm{UO}_{3}$ in the container. Both the infinite array of undamaged containers and a cubic array of 250 damaged containers are subcritical by a minimum safety margin of at least 0.05 for a specified loading of 13.0 $\mathrm{Kg}$. $\mathrm{UO}_{3}$ at 100 Wt: $235 \mathrm{U}$ enrichment. For this condition with 6 Wto water, the actual safety margin is 0.25 for the infinite undamaged array and 0.30 for the finite cubic array of 256 damaged packages. The calculations are summarized in Table 6$\mathrm{X}$ and Figure 6-7.

\subsection{Damaged Finite Array Size Limit}

The damaged 9971 shipping package with a specified loading of $13.0 \mathrm{Kg} . \mathrm{UO}_{3}$ at $80 \mathrm{Wt} . \frac{\mathrm{g}}{6} 235 \mathrm{U}$ enrichment was used in a finite array of packages closely reflected with water, and with optimum interspersed moderation. The arrays were sized to approximate a cuboid using the dimensions of the 9971 shipping package, $2 \mathrm{R} / \mathrm{H}=0.5$. Packages were stacked with twice the number along the $x$ and $y$ axes as in the $z$ axis to approximate a cubic array which is the most reactive credible arrangement for an accident condition.

The conclusion from these calculations is that the damaged array remains subcritical up to two thousand (2000) packages in a cubic arrangement at 80 wt: $235 \mathrm{U}$ enrichment. These calculations are summarized in Table 6-XI and Figure 68 .

The specific standards for a Fissile class I package 4 require two hundred fifty (250) damaged packages be subcritical if stacked together in any arrangement, closely reflected on all sides of the stack by water, and with optimum interspersed hydrogenous moderation. The IAEA regulations require an infinite array of damaged packages to remain subcritical. An infinite array of damaged packages will not remain subcritical unless the $\mathrm{UO}_{3}$ loading is limited to about 20 percent of the container capacity. The 9971 
shipping package does not qualify under IAEA regulations for a transportation index of zero (0) at the required loading.

Table 6-x

Results For 9971 Package Array Analysis

Mass Iimit for Uniform Distribution of $\mathrm{VO}_{3}$ in Bottles

\section{Infinite Undamaged Array \\ 100 Wto 2350, 6 wto Water}

$\begin{array}{ccccc}\text { MIXTURE } & \mathrm{UO}_{3}(\mathrm{KG}) / \mathrm{BOT} & \text { CALCULATED Keff } & \text { Keff BIAS }^{2} & \text { MAX. Keff } \\ \text { 48EW } & 9.15 & 0.82086 \pm 0.00415 & +0.030 & 0.863 \\ \text { 49EW } & 8.0 & 0.79168 \pm 0.00409 & +0.030 & 0.834 \\ \text { 50EW } & 7.0 & 0.76180 \pm 0.00406 & +0.030 & 0.804 \\ \text { 51EW } & 6.5 & 0.70609 \pm 0.00391 & +0.030 & 0.748\end{array}$

\section{Finite Cubic Array, 256 Damaged Packages}

\section{0 wtz $235 \mathrm{v}, 6$ Wtz water}

$\begin{array}{ccccc}\text { MIXTURE } & \mathrm{UO}_{3}(\mathrm{KG}) / \mathrm{BOT} . & \text { CALCULATED Keff } & \text { Keff BIAS }^{2} & \text { MAX. Keff } \\ \text { 48EW } & 9.15 & 0.77910 \pm 0.00472 & +0.030 & 0.823 \\ \text { 49EW } & 8.0 & 0.72755 \pm 0.00393 & +0.030 & 0.769 \\ \text { 50EW } & 7.0 & 0.69299 \pm 0.00472 & +0.030 & 0.737 \\ \text { 51EW } & 6.5 & 0.65279 \pm 0.00442 & +0.030 & 0.696 \\ \text { 52EW } & 5.75 & 0.61699 \pm 0.00426 & +0.030 & 0.660 \\ \text { 53EW } & 4.6 & 0.56047 \pm 0.00387 & +0.030 & 0.602\end{array}$

\section{0 wt? $235 \mathrm{U}, 6$ wt? water}

$\begin{array}{ccccc}\text { MIXTURE } & \text { UO }_{3}(\mathrm{KG}) / \mathrm{BOT} . & \text { CALCULATED Keff } & \text { Keff BIAS }^{2} & \text { MAX. } \text { Keff }^{3} \\ \text { 42EW } & 9.15 & 0.71444 \pm 0.00516 & +0.030 & 0.760 \\ \text { 43EW } & 8.0 & 0.67545 \pm 0.00415 & +0.030 & 0.718 \\ \text { 44EW } & 7.0 & 0.63388 \pm 0.00411 & +0.030 & 0.676 \\ \text { 45EW } & 6.5 & 0.60342 \pm 0.00414 & +0.030 & 0.645 \\ \text { 46EW } & 5.75 & 0.57094 \pm 0.00390 & +0.030 & 0.613 \\ \text { 47EW } & 4.6 & 0.50878 \pm 0.00398 & +0.030 & 0.551\end{array}$

\section{0 wt? 2350 , Dry}

$\begin{array}{ccccc}\text { MIXTURE } & \mathrm{UO}_{3}(\mathrm{KG}) / \mathrm{BOT} . & \text { CALCULATED Keff } & \text { Keff BIAS }^{2} & \text { MAX. Keff } \\ \text { 1A } & 9.15 & 0.65242 \pm 0.00465 & +0.030 & 0.696 \\ \text { 2A } & 8.0 & 0.61558 \pm 0.00344 & +0.030 & 0.656 \\ 3 \mathrm{~A} & 7.0 & 0.58088 \pm 0.00392 & +0.030 & 0.623 \\ 4 \mathrm{~A} & 6.5 & 0.53947 \pm 0.00339 & +0.030 & 0.580 \\ 5 \mathrm{~A} & 5.75 & 0.53381 \pm 0.00371 & +0.030 & 0.575 \\ 6 \mathrm{~A} & 4.6 & 0.48814 \pm 0.00383 & +0.030 & 0.530\end{array}$


PACKING MATERIAL INSIDE INNER CONTANER NORMAL CANE FIBERBOARD INTERSPERSED MODERATION INTERNAL TO PACKAGE EXTERNAL TO INNER CONTAINER
NO HYDROGENOUS MATERLAL

DRY

VOID

DRY AIR

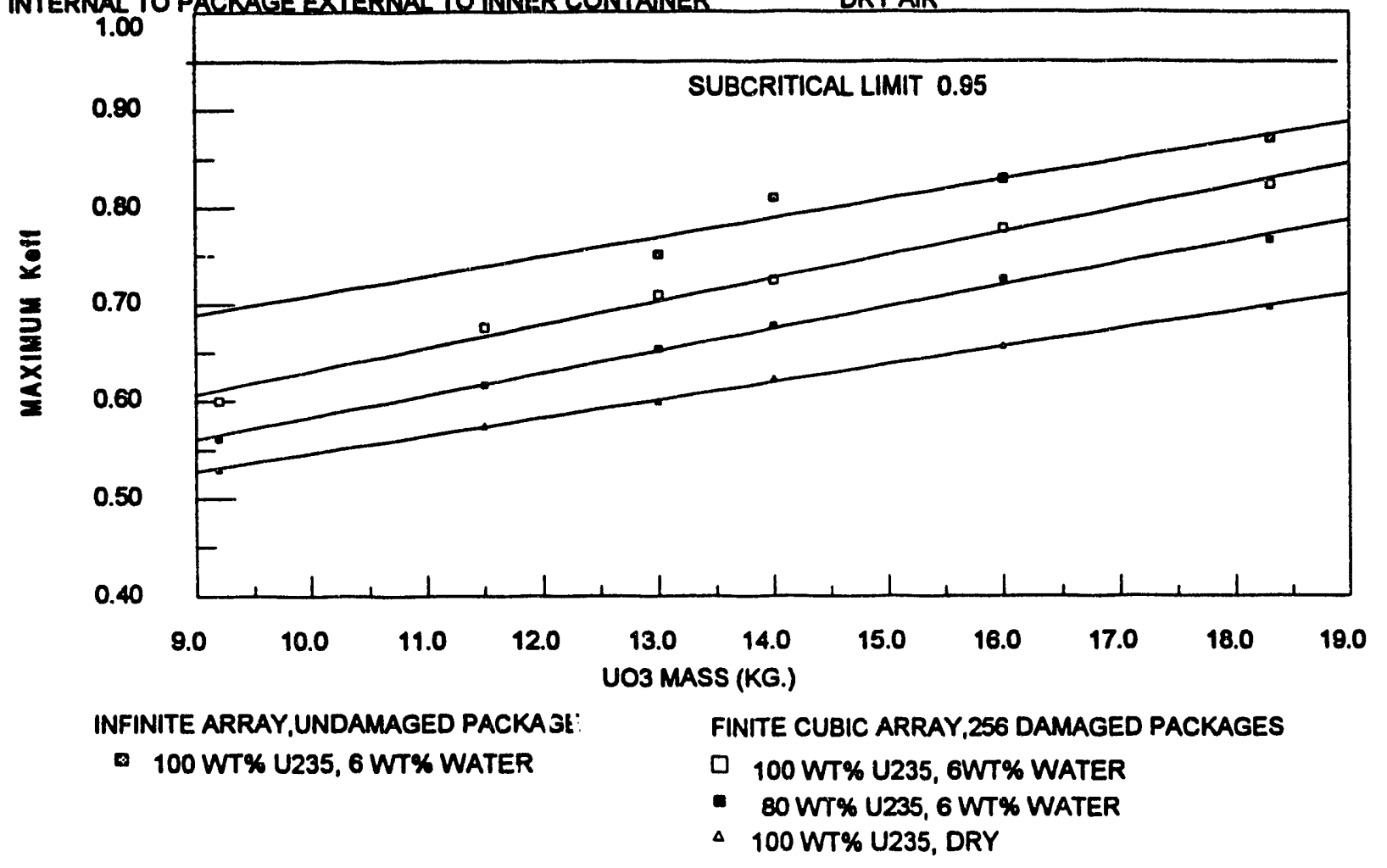

Figure 6-7. Uniform Distribution of $\mathrm{UO}_{3}$ In Bottles (REF: TABLE 6-X) 
Table 6-XI

\title{
Damaged rinite Array
}

\author{
$13.0 \mathrm{Kg} . \mathrm{VO}_{3}, 6 \mathrm{wt}$ Hater \\ $30.5 \mathrm{~cm}$. Water Reflected on All Sides
}

\section{Ntz 2350}

\begin{tabular}{|c|c|c|c|c|c|c|c|c|}
\hline MIXTURE & & RA & & IZI & & CALCULATED $\operatorname{Keff}^{1}$ & $\operatorname{Keff}$ BIAS $^{2}$ & MAX. $\operatorname{Keff} f^{3}$ \\
\hline 42EW & 16 & $\mathbf{x}$ & 16 & $\mathbf{x}$ & 8 & $0.86737 \pm 0.00402$ & +0.030 & 0.909 \\
\hline 42EW & 14 & $\mathbf{x}$ & 14 & $\mathbf{x}$ & 7 & $0.82005 \pm 0.00420$ & +0.030 & 0.863 \\
\hline 42EW & 12 & $\mathbf{x}$ & 12 & $\mathbf{x}$ & 6 & $0.76214 \pm 0.00397$ & +0.030 & 0.804 \\
\hline 42EW & 10 & $\mathbf{x}$ & 10 & $x$ & 5 & $0.68289 \pm 0.00373$ & +0.030 & 0.724 \\
\hline $42 \mathrm{EW}$ & 8 & $\mathbf{x}$ & 8 & $\mathbf{x}$ & 4 & $0.60342 \pm 0.00414$ & +0.030 & 0.646 \\
\hline 42EW & 6 & $\mathbf{x}$ & 6 & $\mathbf{x}$ & 3 & $0.51151 \pm 0.00382$ & +0.030 & 0.553 \\
\hline 42EW & 4 & $\mathbf{x}$ & 4 & $x$ & 2 & $0.40890 \pm 0.00327$ & +0.030 & 0.449 \\
\hline $42 \mathrm{EW}$ & 2 & $\mathbf{x}$ & 2 & $\mathbf{x}$ & 1 & $0.29805 \pm 0.00319$ & +0.030 & 0.338 \\
\hline 42EW & 1 & $\mathbf{x}$ & 1 & $\mathbf{x}$ & 1 & $0.25107 \pm 0.00300$ & +0.030 & 0.290 \\
\hline
\end{tabular}

1 - Uncertainties are one standard deviation (67\% Confidence).

2 - H. K. Clark, "Subcritical Limits for 235 U Systems", Nuc. Sci. Engr. Vol 81 (1982)

3 - Max. Keff = Calculated Keff + 3 Std. Dev. + Keff Bias Max. Keff cannot exceed 0.95 to assure a minimum safety margin of 0.05 in $K_{e f f .}$ 
PACKING MATERIAL INSIDE INNER CONTAINER NORMAL CANE FIBERBOARD INTERSPERSED MODERATION INTERNAL TO PACKAGE EXTERNAL TO INNER CONTANER
NO HYDROGENOUS MATERLAL

DRY

VOID

DRY AR

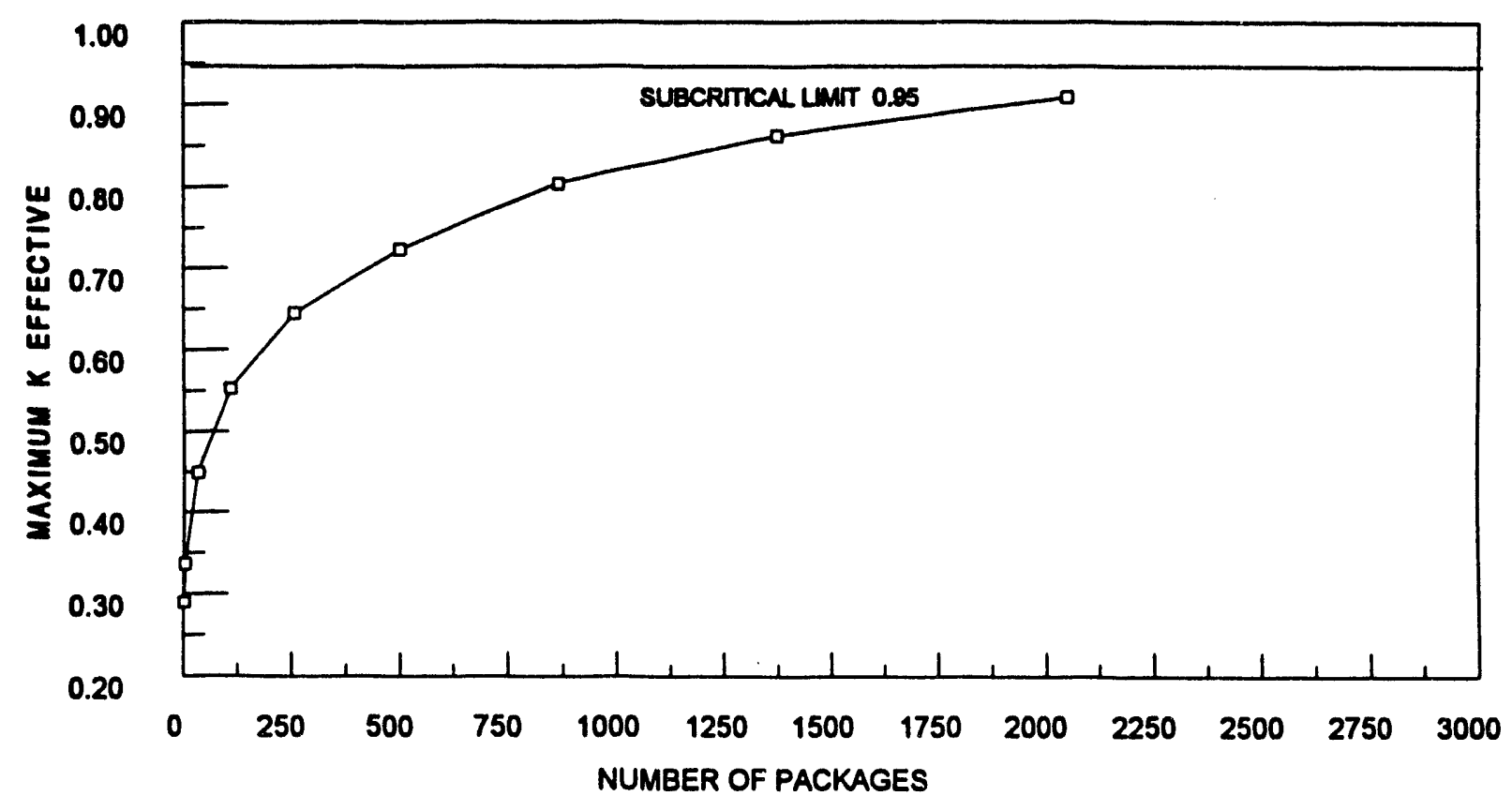

Figure 6-8. Finite Cubic Array of Damaged Packages (REF: TABLE 6-XI). 


\subsection{Alternative Materials For Burned Cane riberboard In Damagad Infinite Array}

Calculations have been performed ${ }^{1}$ which substituted other materials for burned cane fiberboard in the damaged infinite array. The package was assumed to be at optimum condition for all other parameters including 6 wt 8 water content and 80 wt $835 \mathrm{U}$ enrichment. Results of these calculations demonstrate that a minimum safety margin of at least 0.057 in $K_{e f f}$ is retained for any of these conditions.

\subsection{O-Ring Material Effects}

Comparison was made of the different rubber compositions to dry air in the o-ring channels for two $\mathrm{UO}_{3}$ compositions in the infinite damaged array. 1 These results indicate that changes in Keff are all in the last significant digit and are of small magnitude. These results are within the scatter of the stochastic sampling performed by the rme-IV/CG and represent random variations about a mean. There is no indication of any significant difference if one uses dry air, neoprene rubber, or buna-N rubber in o-ring channels in the calculations.

\subsubsection{Displacement of Inner container In Damaged Areay}

All calculations of the damaged array assumed the inner package was located at or near its nominal position, and the spacing of the full package was assumed the same as for the undamaged array. The basis of these assumptions will be examined.

Assuming the spacing of packages in the damaged array is the same as for the undamaged array should produce slightly higher calculated $K_{\text {eff }}$ values. The damaged package will have dents and bends following the drop test, and thus should not be able to be stacked as uniformly or as closely as the undamaged package array. A higher package spacing in the damaged array will produce slightly lower calculated $K_{e f f}$ values. 
No calculations were performed with the inner container displaced from its normal position laxially only for the undamaged array, and in multiple directions for the damaged array) for the following reasons:

- The primary interaction between packages in the infinite array is the radial direction (more surface area than axially). Displacing the inner package axially for the undamaged array would tend to decrease the calculated reactivity by a very small amount because of reduced radial interaction with little change in the axial interaction (it might increase in the direction of displacement, but will decrease in the opposite direction).

- Displacing the entire inner contents of damaged packages will permit adjacent inner packages to be moved closer. However, this will also increase the spacing from other inner packages. This effect has been examined for a similar package18 (Type 9966) and for waste drums 19 and found to decrease the calculated reactivity in all cases compared to inner package nominal position reactivities.

\section{4 .5 use of Smaller or Iarger Plastic Botties}

The bottles used in this evaluation were nominal 2.0Liter plastic wide-mouth containers. Specifications for these bottlesil list brim capacities of 2.14 Liters (HD Polyethylene) and 2.2 Iiters (Polypropylene), although measurement of actual bottles gives higher volumes (less plastic). Use of bottles of smaller volume is unquestionably safer because product density must be higher (for a $6.5 \mathrm{~kg}$. dry loading), or mass of dry product must decrease, both producing a lower reactivity ( $\left.k_{e f f}\right)$ in all calculations shown previously. 1

Bottles of slightly higher volume than appear in this evaluation may be used. A bottle volume limit of 2.4 liters is justified by examination of the results that appear in the evaluation. 1 Increasing the permitted bottle volume beyond 2.4 liters does not appear possible within Fissile Class I restrictions. All bottles are assumed to have similar shape to the bottle used in this evaluation. 


\subsection{CRITUCAITTY BRNCBYARK MXPFRIMTNTS}

The rinNo-IV/CG Monte Carlo criticality code has been extensively validated using the Hansen-Roach cross section library for a range of uranium enrichments, reflection conditions and interacting unit arrays that more than adequately describe the conditions of this evaluation. These validation studies are documented in References 20 through 27, and only a summary of the pertinent results of these studies will be presented here.

For uranium solutions or wet uranium powders the correlated bias of the KrwO-IV/CG calculation of more than 500 experiments was shown to vary as a function of the $H / 235 \mathrm{U}$ atom ratio in the uranium-water mixture. The largest bias was found to occur for $\mathrm{H} / 235 \mathrm{U}$ atom ratios in the range from 50 to 125; the nominal bias value being +0.030 (an experiment with $K_{\text {eff }}=1$ is calculated to be 0.970 ).

The Monte Carlo criticality calculation of Keff in IuNO-IV/CG is based on a stochastic sampling technique. The errors of the calcuiation are based on averaging the Keff values calculated in several batches of neutron histories, and expressing the error in a standard deviation assuming a gaussian error distribution function. The confidence level (percentage of total area under the error distribution function for a specified standard deviation rangel for various values of standard deviation is shown in Table 6-XII.

\begin{tabular}{lc} 
Table & $\begin{array}{c}\text { 6-XII } \\
\text { Confidence Ierel }\end{array}$ \\
\hline Value \pm 1 Std. Dev. & $68.26 \%$ \\
Value \pm 2 Std. Dev. & $95.46 \%$ \\
Value \pm 3 Std. Dev. & $99.74 \%$
\end{tabular}

To use the data in Table 6-XII a Maximum Keff value is defined which expresses the worst possible value of Keff credible from a value computed by KENO-IV/CG. This Max. Keff is defined as:

Max. Keff $=$ Calculated Keff + Keff Bias +3 Std. Dev.

By its definition this Max. Keff places delayed criticality at a value of 1.0 , and prompt criticality at about 1.01 . In addition, this definition increases the confidence level to $99.87 \%$ because all errors are assumed additive only in the positive direction, thus eliminating the $0.13 \%$ area in the negative direction. 
In all tables of results in Section 6.4 a Maximum Keff value is assigned to each calculation. This is an estimate of the worst possible value of Keff credible for each calculation. The KMNO-IV/CG value of Standard Deviation is used to assign the error due to the stochastic sampling in the code. The Keff Bias taken from validated correlations in Reference 21 is a maximum bias of 0.03 . In addition, a margin of 0.05 in Max. Keff is an additional required margin to assure safety from unforeseen circumstances. The highest permitted value of Max. Keff is 0.95 which provides additional assurance of criticality safety for shipments in the 9971 package. 


\subsection{RTHFRMNCMS}

1. Finch, D. R., Nuclear Criticality Safety Evaluation of sRs 9971 shipping Package, WSRC-TR-91-445, July 1991 .

2. American National Standards Institute, Nuclear Criticality safety in Oparations with rissile Materials Outside Reactors, er 3, 1983, Reaffirmed November 30,1988 .

3. U.S. Department of Energy, safety of Nuclear racilities, USDOE Order 5480.5, September 23, 1986.

4. U.S. Code of Federal Regulations, Part 71 - Packaging and rransportation of Radioactivo Material, 10CFR71, Paragraphs

5. U.S. Code of Federal Regulations, Rart 173 - Shippers - General Reguirements for shipments and Packagings, 49CFR173, Paragraph 173.455, November 1, 1987.

6. Regulations for the Safe Transport of Radioactive Materials - 1985 Edition, Safety Series No. 5. STI/PUB/607 (Vienna: IAEA) (1985).

7. Letter D. A. Reed, Martin-Marietta Energy Systems, Inc. to D. R. Finch, Westinghouse Savannah River Company, Iypical Densities of Y-12 Enriched Oranium Trioxido, May 31, 1991, See Appendix A.

8. Letter Patrick Adamson, Martin-Marietta Energy Systems, Inc. to James A. Purcell, Westinghouse Savannah River Company, summary of $00_{3}$ Moisture study Work, March 28, 1591, See Appendix A.

9. U.S. Department of Energy, Savannah River Site, Separations/USF 221-H, USF-16, Engineering Drawings:

\section{ritis}

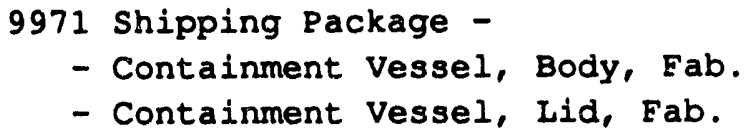

Gro Draring Iumbar

W2012410 Rev. 0 W2012411 Rev. 0 
10. U.S. Department of Energy, Savannah River Site, Separations/USF 221-H, USF-16, Engineering Drawings:

Titie

Title
9971 Shipping Package -
- General Notes
- Final Assembly
- Fiberboard Cradle, Assembly
- Fiberboard Cover, Assembly
- Fiberboard Cradle, Support Plate
- Fiberboard Cover, Fiberboard Disks
- Fiberboard Cover, Stainless Disk
- Stainless Steel Drum, Assembly

EFD Drawing Number

\begin{tabular}{|c|c|}
\hline 2012407 & Rev \\
\hline 2012408 & ev. \\
\hline 2012409 & ev \\
\hline พ2012412 & ev \\
\hline พ2012413 & ex \\
\hline W2012414 & $e v$ \\
\hline พ2012415 & \\
\hline 2012417 & \\
\hline
\end{tabular}

11. Nalge Company, Nalgene Labware 1990, Rochester, NY, (1990) Pgs. 12, 167, 173, 179, See Appendix A.

12. R. S. Maurer, Criticality Computation for the 9971 USF Packinging, SRT-PTG-92-0099, Aug. 4, 1992.

13. U.S. Department of Energy, Savannah River Site, Separations/USF, 221-H, USF-16, Engineering Drawings:

Titie

9971 Shipping Package - General Notes
BFD Draying Number

W2012407 Rev. 0

14. J. T. West, III, et al., INWO-IV/CG, The Combinatorial Geometry Version of the KENO Monte Carlo Criticality safety Program, NUREG/CR-0709, Oak Ridge National Laboratory, Oak Ridge, TN, September 1979 .

15. G. E. Hansen and W. H. Roach, Six and Sixteen Group Cross sections For rast and Intermediate Critical Assemblies, LAMS-2543, Los Alamos National Laboratory, Los Alamos, NM, 1961.

16. H. K. Clark, JoshUA Nuclear Criticality safety Modules, DPSTM-86-700-3, Section 3, Savannah River Laboratory, Aiken, SC, 1986.

17. H. K. Clark, JoshoA Nuclear Criticality Safety Modules, DPSTM-86-700-3, Section 7, Savannah River Laboratory, Aiken, SC, 1986. 
18. Safety Analysis Report for Packaging - SRP Type 9966 Package, DPSPU-83-124-1, Savannah River Plant, Aiken, SC, 1984.

19. W. A. Blyckert and R. D. Carter, Criticality Parameters of 55-Galion Waste Drum Arrays, RHO-SA183, Rockwell Hanford Operations, Richland, WA, November 7. 1980 .

20. H. K. Clark, Subcritical Limits For 2350 systems, DPST-80-415, Savannah River Laboratory, Aiken, SC, 1981.

21. H. K. Clark, "Subcritical Limits for 235 U systems", Nuc. sci. Engr. 81, 1982.

22. H. K. Clark, Correlations of KENO with Critical Experiments with Interacting Units, DPST-82-317, Savannah River February 12, 1982.

23. H. K. Clark, Correlations with Critical Experiments with Concrete-Reflected Systems, DPST-82-428, Savannah River Laboratory, Aiken, SC, March 25, 1982.

24. H. K. Clark, Correlations with Critical Experiments with Cylinders surrounded Iaterally By Various Thicknesses of watex, DPST-84-428, Savannah River Laboratory, April 6, 1984.

25. H. K. Clark, Correlations with MARx 16 Experiments, DPST-83-1025, Savannah River Laboratory, Aiken, SC, November $29,1983$.

26. H. K. Clark, Correlations with Critical Experiments with Cadmium and Thick steel Reflectors, DPST-84383, Savannah River Laboratory, Aiken, SC, April 11, 1984 .

27. H. K. Clark, Miscellaneous Correlations, DPST-84714, Savannah River Laboratory, Aiken, SC, August 22, 1984 . 

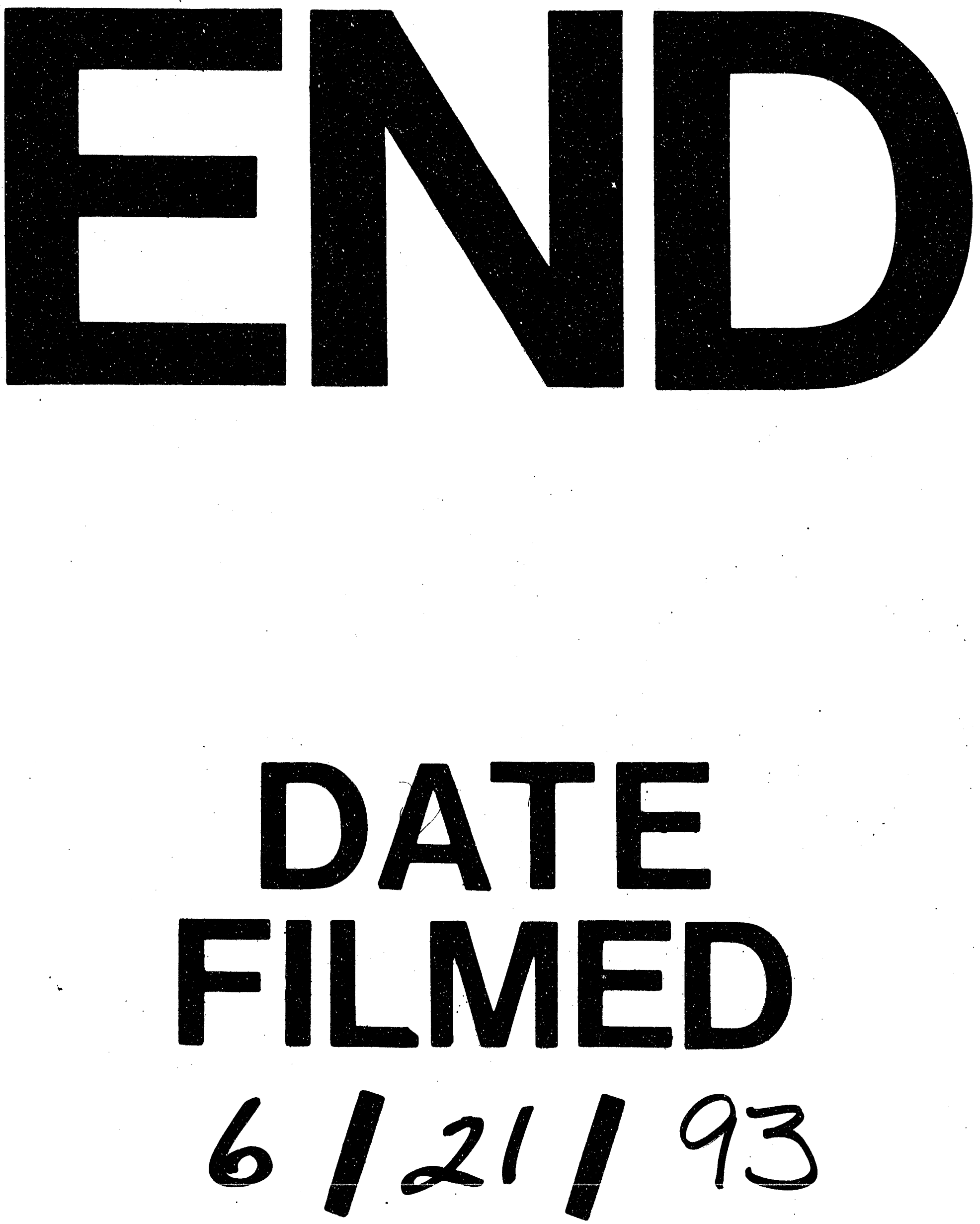

1 
